\title{
Determining the energy performance of rotating machine for fluid flow
}

\author{
Albertino Giovani Roza ${ }^{1}$, Ammar Almaslamani ${ }^{1}$, Elena Beatrice Tănase ${ }^{1}$, Nicolae Băran ${ }^{1}$ \\ and Mihaela Constantin ${ }^{1, *}$ \\ ${ }^{1}$ University Politehnica of Bucharest, Faculty of Mechanical Engineering and Mechatronics, Splaiul \\ Independenței, no. 313, Bucharest, Romania
}

\begin{abstract}
The rotating machine, to which the paper relates, refers to the following:

- A rotating machine construction solution that can be used as a power machine (steam engine, pneumatic engine)

- The same construction solution can be used as a working machine (pump, fan, and compressor). The constructive solution and the operating principle of the rotating machine are presented, the flow rate and the machine power computation model is indicated. At the end of the paper, the machine effective efficiency is experimentally determined.
\end{abstract}

\section{Introduction}

The machines are aggregates for converting the energies from one to another by using a mobile body (piston, profiled rotor, and palette).

The machine subdivided into more two broad categories:

a- Force machine (motor machine)

b- Working a machine which converts mechanical energy into another form of energy (compressors, fans, pumps).

Regarding the flow parameters variation, working and force machines that are crossed by fluids, are classified as follows:

a. Hydraulic machines, which are driven or circulate liquids, where the thermal phenomena are neglected.

b. Thermal machine, which circulates gases or vapors (or are driven by these) to which thermal the phenomena that appear cannot be neglected.

The most common are thermal machines, after the principle of operation, are classified as follows [1]:

a. Machines with a reciprocating motion piston

b. Rotating machines (profiled rotors or palettes)

c. Machines (motors) with reaction

Regarding the nature of the motor fluid, thermal machines are classified as follows:

a Steam machines (piston or rotor)

b. Gas machine (internal combustion engines, gas turbines, jet engines). 


\section{Presentation of the rotating machine}

The machine can function as follows:

- pump, blower, and fan, (working machine); the machine receives a motor torque at the shaft (9) and the discharge pressure $\left(p_{r}\right)$ will be higher than the suction fluid pressure $\left(p_{a}\right)$;

- As a power machine (hydraulic motor, pneumatic engine, steam or gas engine) in this case, the machine delivers a motor torque outward through the shaft (9).

The present paper presents the operation of the machine as a rotating volumetric pump with profiled rotors $[1,2]$.

The machine (Figure 1) consists of has two identical rotors $(2,5)$ with a special shape which rotates within a case $(1,4)$ with the same speed. The rotation of the two rotors is synchronous and is provided by a cylindrical gear consisting of two inclined gear wheels located in or out the machine.

The gear wheels provide a rotational movement so that the rotating pistons (6) of the upper rotor enters the cavities (10) of the lower rotor. The gear wheels have the same division diameter and are mounted on shafts 7 and 9.

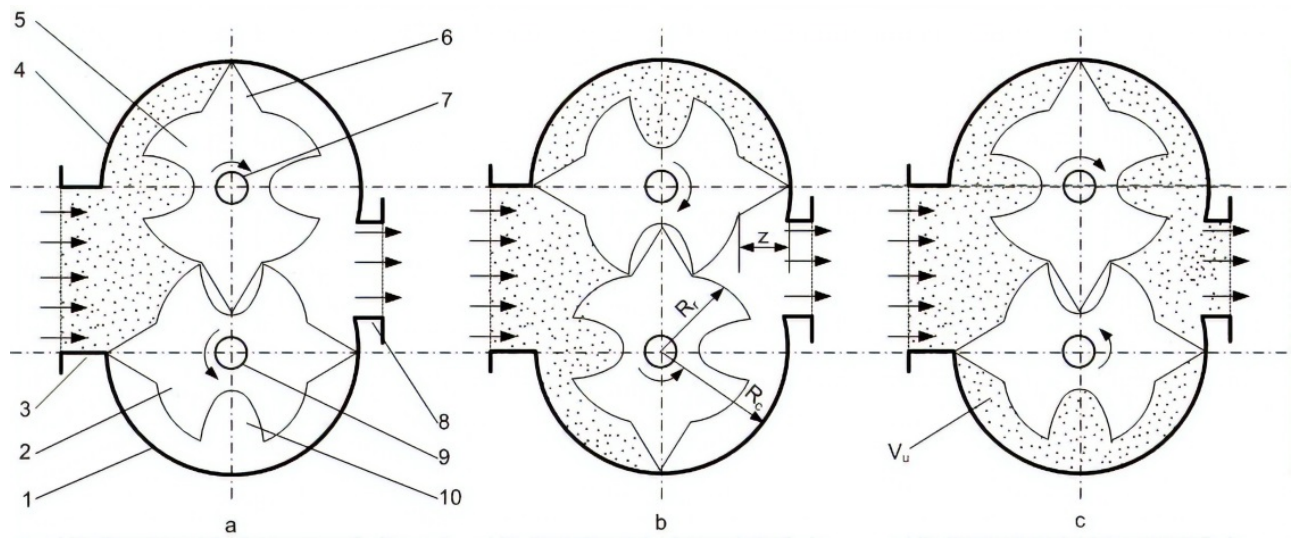

Fig. 1. The functioning principle of the rotating volumetric machine 1- bottom case; 2- bottom rotor; 3-suction chamber; 4- top case; 5- top rotor; 6- piston; 7-driven shaft; 8-drain chamber; 9-driving shaft; 10 -cavity in which the top rotor piston enters a, b, c, the rotor's position after a $90^{\circ}$ rotation

The sucked fluid (Figure 1.a) is transported to the discharge and after a $90^{\circ}$ rotation of both rotors - the position in Figure $1 \mathrm{~b}$ and then the position in Figure 1c is reached.

After a $180^{\circ}$ rotation of the fluid in the useful volume $V_{u}$ (figure 1.c), i.e. in the space between the pistons, the bottom case (1) and the bottom rotor (3) will be forced to leave the case and penetrate into the drain pipe.

\section{Calculation of the volumetric flow rate and the driving power of the machine}

The fluid entering the suction chamber is transported to the discharge chamber regardless of its nature or composition.

This type of rotating machine belongs to the category of driving machines (not actuating) and can transport: clean liquids or suspensions, polyphase fluids (water + ash, water + fuel oil, etc.), wastewater, rheological fluids, gases, vapors etc.

The construction solution is simple, does not require special execution technologies and has a higher degree of reliability. This type of machine can be used in the following fields: 
energy industry, petrochemical industry, wastewater treatment plants, mining, and agriculture.

When operating as a pump or compressor, at a full rotation of the shaft (9), two volumes $[3,4]$ will be transported from aspiration to discharge:

$$
V_{u}=\left(\pi R_{c}^{2}-\pi R_{r}^{2}\right) l\left[m^{3} / r o t\right]
$$

The case radius $\left(\mathrm{R}_{\mathrm{c}}\right)$ is the sum of the rotor radius $\left(\mathrm{R}_{\mathrm{r}}\right)$ and the piston height $(\mathrm{z})$,:

$$
R_{c}=R_{r}+z[m]
$$

it results:

$$
V_{u}=l \cdot z\left(z+2 R_{r}\right)\left[m^{3} / r o t\right]
$$

The volumetric flow rate of a single rotor:

$$
\dot{V}_{u}=l \cdot z\left(z+2 R_{r}\right) \cdot \frac{n_{r}}{60}\left[m^{3} / s\right]
$$

The flow rate for the whole machine with two identical rotors is:

$$
\dot{V}_{u m}=2 \dot{V}_{u}=l \cdot z\left(z+2 R_{r}\right) \cdot \frac{n_{r}}{60}\left[\mathrm{~m}^{3} / s\right]
$$

From the above relations, it is observed that the volumetric flow rate increases linearly with the rotor radius and length $\left(1, R_{r}\right)$ and with the speed $(n)$.

The driving power is obtained (theoretical) with the relation [4]:

$$
P_{m}=V_{m} \cdot \Delta p[W]
$$

where the flow rate from the previous relations is replaced and the following is obtained:

$$
P_{m}=l z \Delta p\left(2 R_{r}+z\right) \cdot \frac{n_{r}}{30}[W]
$$

\section{The experimental installation scheme}

The scheme of the experimental installation is presented in figure 2 .

The working fluid (air, water, oil) is taken from the tank (2) by means of the profiled rotors (5). The machine can carry both gases (air) and liquids (water, oil).

The speed of the electric motor (6) acting on the pump is controlled by a frequency converter (7).

At the pump outlet, the fluid passes through an electromagnetic flow meter (10) and a flow control valve (11). Then the liquid is pumped to $\mathrm{h}=2 \mathrm{~m}$ and finally reaches the tank (2).

The liquid layer in the tank has a height of $0.5 \mathrm{~m}$, height that ensures that the pump will always be "drowned" (figure 2).

This pump transmits any fluid, but the electromagnetic flow meter determines the state: the electrical conductivity of the fluid to be measured is greater than $200 \mu \mathrm{S} / \mathrm{m}$; 
consequently, for the reported flows subject to the measurements, reference is made to water only.

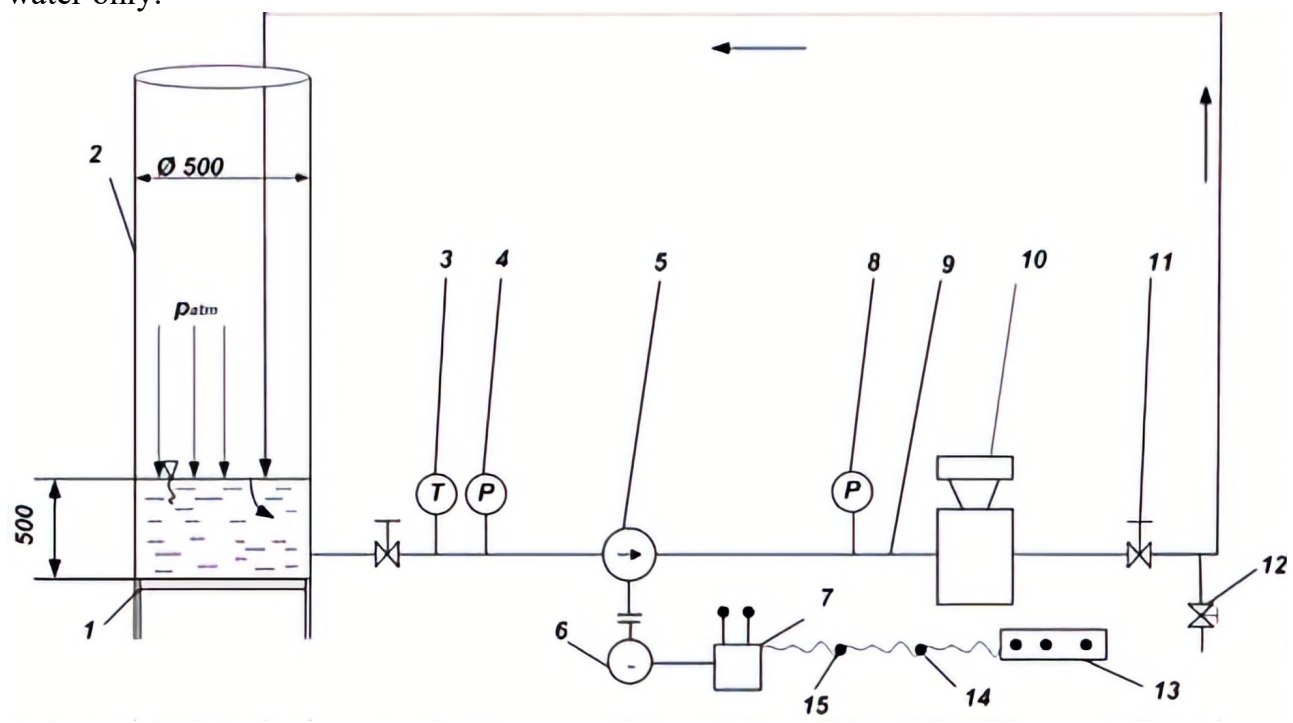

Fig. 2. The experimental installation scheme

1 - tank support; 2- water tank; 3 - thermometer; 4 - manometer; 5 - pump; 6 - electric motor;

7 - speed regulating device; 8 - manometer; 9 - duct $\varnothing 50 \times 3 \mathrm{~mm}$; 10 - electromagnetic flow meter;

11 - flow control valve; 12 - fluid circuit drain valve; 13 - 380 VAC source; 14 - multimeter;

15 - ammeter.

The pipeline path is built of $50 \times 3 \mathrm{~mm}$ transparent Plexiglas, which allows a better flow visualization. On the fluid circulation pipe, there are manometers, thermometers, an electromagnetic flow meter; the pump speed can be changed by means of a frequency inverter.

\section{The purpose of experimental researches}

The effective efficiency of the rotating machine is to be determined; for this purpose, the fluid flow velocity through the pipes is calculated to determine the linear and local pressure losses.

\subsection{Determining the fluid flow velocity through the pipes}

In the flow calculation equation, the dimensions of the built model are replaced:

$-1=0.05 \mathrm{~m} ; \mathrm{z}=0.03 \mathrm{~m} ; \mathrm{R}_{\mathrm{f}}=0.05 \mathrm{~m}$;

-the machine speed was chosen: 100, 150, 200 and 250 [rpm];

- the working fluid is water with a density of $1000\left[\mathrm{~kg} / \mathrm{m}^{3}\right]$.

The values of the water flow rate flowing through the pump are shown in Table 1; the water circuit in the installation is through a $\varnothing 50 \times 3 \mathrm{~mm}$ pipe so that the inside diameter is $44 \mathrm{~mm}$. It is possible to calculate the water velocity in the circuit $[5,6]$.

$$
w=\frac{\dot{V}}{\pi \frac{d^{2}}{4}}=4 \frac{\dot{V}}{\pi d^{2}}[\mathrm{~m} / \mathrm{s}]
$$

The computation results are presented in Table 1. 
Table 1. Water flow rate and velocity values.

\begin{tabular}{|c|c|c|c|c|}
\hline Fluid (water) $\mathrm{n}_{\mathrm{r}}[\mathrm{rot} / \mathrm{min}]$ & 100 & 150 & 200 & 250 \\
\hline$\dot{V}\left[\mathrm{~m}^{3} / \mathrm{s}\right]$ & 0.00204 & 0.00306 & 0.00408 & 0.00510 \\
\hline $\mathrm{w}[\mathrm{m} / \mathrm{s}]$ & 1.34138 & 2.01207 & 2.68276 & 3.35345 \\
\hline
\end{tabular}

\subsection{Determining the power absorbed at the rotating machine coupler}

After measuring the voltage (U) and the intensity of three-phase electric current (I), the electrical power absorbed by the electric motor is determined $[7,8]$ :

$$
P_{m, e}=\sqrt{3} U I \cos \varphi[W]
$$

The electric motor has the following characteristics:

- Electricity efficiency: $\eta_{\mathrm{m}, \mathrm{e}}=0.747$;

- The factor of the power: $\cos \varphi=0.71$.

The power consumed by the electric motor $\left(\mathrm{P}_{\mathrm{m}, \mathrm{e}}\right)$ is also determined by calculation, taking into account the efficiency of the electric motor, determining the power at the coupling of the machine $\left(P_{c m}\right)$.

$$
P_{c m}=P_{m, e} \cdot \eta_{m, e}[W]
$$

Subsequently, from $\mathrm{P}_{\mathrm{cm}}$, the power to overcome the hydrostatic load of the pump and of the linear and local hydraulic resistances on the installation circuit is removed; the remaining value must be equal to the power consumption of viscous friction $\left(\mathrm{P}_{\mathrm{tf}}\right)$. The efficiency of the volumetric pump will be:

$$
\eta_{e}=\frac{P_{\mathrm{H}}+P_{\Delta p}}{P_{c m}}
$$

With relations (1) and (2), based on experimental data (U, I), the results are shown in Table 2 , the working fluid being water.

Table 2. $\mathrm{P}_{\mathrm{m}, \mathrm{e}}$ and $\mathrm{P}_{\mathrm{cm}}$ values

\begin{tabular}{|c|c|c|c|c|c|}
\hline No & $\mathrm{n}_{\mathrm{r}}[\mathrm{rot} / \mathrm{min}]$ & $\mathrm{I}[\mathrm{A}]$ & $\mathrm{P}_{\mathrm{m}, \mathrm{e}}[\mathrm{W}]$ & $\mathrm{P}_{\mathrm{cm}}[\mathrm{W}]$ & $\mathrm{U}[\mathrm{V}]$ \\
\hline 1 & 100 & 0.56 & 264.61 & 197.66 & 384.70 \\
\hline 2 & 150 & 0.60 & 283.14 & 211.50 & 384.20 \\
\hline 3 & 200 & 0.75 & 354.67 & 264.93 & 385.00 \\
\hline 4 & 250 & 1.02 & 481.60 & 359.75 & 384.40 \\
\hline
\end{tabular}

\subsection{Determining the power to overcome the hydrostatic load and the hydraulic resistances inside the circuit}

\subsubsection{Determining the power to overcome the hydrostatic load}

For the correct calculation, $\mathrm{n}$ is selected 200 [ $\mathrm{rot} / \mathrm{min}$ ]. 


$$
P_{H}=\dot{V} \cdot \Delta p_{H}[W]
$$

where:

$\dot{V}$ - volumetric flow rate $\left[\mathrm{m}^{3} / \mathrm{s}\right]$

$\Delta \mathrm{p}_{\mathrm{H}}$ - pressure increase $\left[\mathrm{N} / \mathrm{m}^{2}\right]$

$\Delta \mathrm{p}_{\mathrm{H}}=\rho \mathrm{gH}=10^{3} \cdot 9.81 \cdot 1.5=14715\left[\mathrm{~N} / \mathrm{m}^{2}\right]$

$$
P_{H}=4.08 \cdot 10^{-3} \cdot 14715=60[\mathrm{~W}]
$$

5.3.2 Determining the power consumed to overcome local hydraulic resistances inside the circuit [9-11]

Determining of linear pressure losses is made when $n_{r}=200$ [rot $\left./ \mathrm{min}\right]$.

The following are known:

- fluid flow rate inside a $\varnothing 50 \times 3 \mathrm{~mm}$ pipe: $\dot{V}=4.08 \cdot 10^{-3}\left[\mathrm{~m}^{3} / \mathrm{s}\right]$

- water velocity inside the pipe: $w=2.68[\mathrm{~m} / \mathrm{s}]$;

- length of the path: $1=6 \mathrm{~m}$.

The power to overcome linear hydraulic resistances:

$$
P_{\text {lin }}=\dot{V} \cdot \Delta p=4.08 \cdot 10^{-3} \cdot 10283.89=42[\mathrm{~W}]
$$

The power consumed to overcome local hydraulic resistances:

$$
P_{l o c}=\dot{V} \cdot \Delta p=4.08 \cdot 10^{-3} \cdot 23701.92=96.7[\mathrm{~W}]
$$

So:

$$
P_{\Delta p}=P_{l i n}+P_{l o c}=42+96.7=138.7[\mathrm{~W}]
$$

\section{Determining the effective efficiency of the rotating working machine}

Relation (11) is resumed:

$$
\eta_{e}=\frac{P_{H}+P_{\Delta p}}{P_{c m}}=\frac{60+138.7}{264.93}=0.75
$$

0.75 is a good value compared to other literature results [11, 12].

The energy balance of the installation is as follows:

$$
\begin{aligned}
& \rightarrow P_{H}=60 \mathrm{~W} \\
P_{c m}=264.93 \mathrm{~W} & \rightarrow P_{\Delta p}=138.7 \mathrm{~W} \\
& \rightarrow P_{f}=66.23 \mathrm{~W}
\end{aligned}
$$

$\mathrm{P}_{\mathrm{f}}$ is the power absorbed by the viscous friction between the case and the rotors, calculated as a difference:

$$
P_{f}=P_{c m}-\left(P_{H}+P_{\Delta p}\right)[W]
$$


Similarly, the calculations are made for $\mathrm{n}_{\mathrm{r}}$ : 150, 200, 250 [rot/min] and presented in Table 3 results.

Table 3. Values of $\eta_{\mathrm{e}}$ for different machine speeds

\begin{tabular}{|c|c|c|c|c|c|}
\hline $\mathbf{n}_{\mathbf{r}}[\mathrm{rot} / \mathrm{min}]$ & $\mathbf{P}_{\mathbf{c m}}[\mathrm{W}]$ & $\boldsymbol{\Delta} \mathbf{P}_{\boldsymbol{\Delta p t}}[\mathrm{W}]$ & $\boldsymbol{P}_{\boldsymbol{H}}[\mathrm{W}]$ & $\boldsymbol{P}_{\boldsymbol{t}}[\mathrm{W}]$ & $\eta_{\mathrm{e}}$ \\
\hline 100 & 197.66 & 17.57 & 30.01 & 47.58 & 0.24 \\
\hline 150 & 211.50 & 57.11 & 45.02 & 102.53 & 0.48 \\
\hline 200 & 264.93 & 138.7 & 60.03 & 198.74 & 0.75 \\
\hline 250 & 359.75 & 255.2 & 75.04 & 258 & 0.719 \\
\hline
\end{tabular}

Considering the data in Table 3, the function $\eta_{e}=f\left(n_{r}\right)$ was plotted.

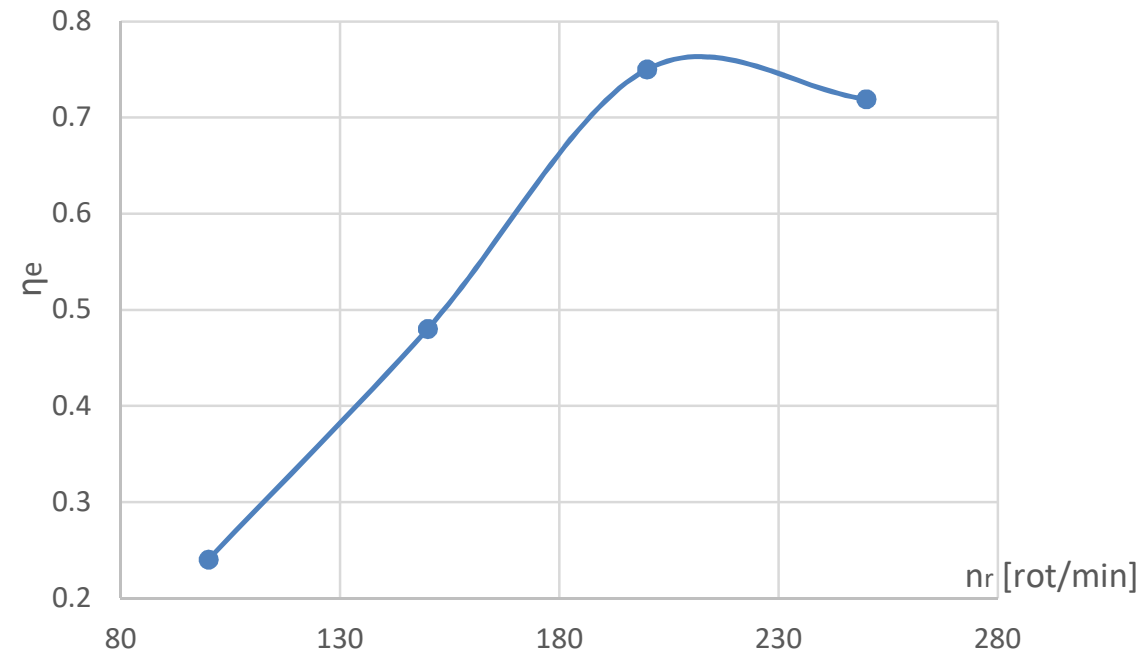

Fig. 3. The graph of the function $\eta_{e}=f\left(n_{r}\right)$

From Figure 3 it is confirmed that with the speed increase, which is the $\omega$ increase, the machine efficiency will increase to a certain value and then begin to decrease; this is because increasing the speed increases the flow rate, thus increasing pressure loss on the hydraulic circuit.

The values obtained for $\eta_{\mathrm{e}}$ are satisfactory with the data from the literature [12-15].

\section{Conclusions}

- Rotating working machines have the advantage of transforming the moment received to the engine shaft into potential pressure with minimal energy loss;

- The presented solution can convey clean or suspended liquids as well as rheological fluids or gases;

- The effective machine efficiency is influenced by the fluid nature, machine speed, and fluid viscosity. 


\section{References}

1. N. Băran, I. Căluşaru, A. Detzortzis, JMSE A 2, Research Regarding the Testing of a New Type of Rotating Machine with Profiled Rotors, 3, 372-376, (2012).

2. A. Motorga, Ph.D. Thesis, Influența parametrilor constructivi și funcționali asupra performanțelor mașinilor rotative cu rotoare profilate, University Politehnica of Bucharest, (2011).

3. N. Băran, Mașini termice rotative -Mașini de forță, Mașini de lucru, Editura MATRIX ROM, București, (2001).

4. N. Băran, Mașini termice rotative de lucru, Editura Matrix Rom, București, 2003.

5. Al. Dobrovicescu, N. Băran, ș.a., Elemente de termodinamică tehnică, Editura POLITEHNICA-PRESS, București, (2009).

6. C. Isbăşoiu, Tratat de mecanica fluidelor, Editura AGIR, București, (2011).

7. M. Preda, P. Cristea, Bazele Electrotehnicii-Circuite electrice, 2, Editura Didactică și Pedagogică, București, (1980).

8. C-tin Ghiță, Mașini și acționări electrice, Editura I.C.P.E., București, (1997).

9. G. Bar-Meir, Basics of fluid mechanics, Chicago, (2011).

10. P.G. Kiselev, Îndrumar pentru calcule hidraulice, Editura Tehnică, București, (1998).

11. I.E. Idelcik, Indrumar pentru calculul rezistențelor hidraulice, Editura Tehnică, București, (1994).

12. M. Exarhu, Mașini și instalații hidraulice și pneumatice, Editura ANDOR TIP S.R.L., București, (2006).

13. A. Beazit, Mașini hidropneumatice navale, Editura Academiei Navale Mircea cel Bătrân, Constanța, (2010).

14. Y. H. Kang, H.H. Vu, Journal of Mech. Sci. and Tech., A newly developed rotor profile for lobe pumps: Generation and numerical performance assessment, Taiwan, Marc, 28, Issue 3, 915-926, (2014).

15. V. Burchiu, L. Gheorghiu, A. Dudau, Ghidul utilizatorului de pompe, Editura AtlasPress, București (2006). 